\title{
The Nexus between Tourism Activities and Environmental Degradation: Romanian Tourists' Opinions
}

\author{
Mirela Ștefănică ${ }^{1}\left(\mathbb{D}\right.$, Christiana Brigitte Sandu ${ }^{2} \mathbb{C}$, Gina Ionela Butnaru ${ }^{1, *(\mathbb{C}}$ and Alina-Petronela Haller ${ }^{3} \mathbb{C}$ \\ 1 Department of Management, Marketing and Business Administration, Faculty of Economics and Business \\ Administration, Alexandru Ioan Cuza University of Iași, 700505 Iași, Romania; mirela.stefanica@uaic.ro \\ 2 Department of Accounting, Business Information Systems and Statistics, Faculty of Economics and Business \\ Administration, Alexandru Ioan Cuza University of Iași, 700505 Iași, Romania; christiana.balan@uaic.ro \\ 3 Gheorghe Zane Institute for Economic and Social Research, Iași Branch of Romanian Academy, 700488 Iași, \\ Romania; hallalinap@gmail.com \\ * Correspondence: gina.butnaru@uaic.ro
}

Citation: Ștefănică, M.; Sandu, C.B.; Butnaru, G.I.; Haller, A.-P. The Nexus between Tourism Activities and Environmental Degradation: Romanian Tourists' Opinions. Sustainability 2021, 13, 9210. https:// doi.org/10.3390/su13169210

Academic Editor: Ronda J. Green

Received: 25 June 2021

Accepted: 14 August 2021

Published: 17 August 2021

Publisher's Note: MDPI stays neutral with regard to jurisdictional claims in published maps and institutional affiliations.

Copyright: (c) 2021 by the authors. Licensee MDPI, Basel, Switzerland. This article is an open access article distributed under the terms and conditions of the Creative Commons Attribution (CC BY) license (https:// creativecommons.org/licenses/by/ $4.0 /)$.

\begin{abstract}
This paper aims to analyse the nexus between tourism activities, including tourists' circulation, accommodation or entertainment, and environmental degradation. Consequently, the conceptual framework captures the complexity of the nexus between tourism and the environment, given that tourism activities can be performed by tourists or for tourists and that tourism depends on the environmental quality, and, consequently, we highlight the impact of tourism activities on biodiversity loss through the pollution effects that they generate, i.e., air pollution, water pollution, or noise pollution, as well as their contribution to waste increase or to the depletion of natural resources. To achieve this goal, we apply structural equation modelling based on partial least squares analysis (PLS). The results based on tourists' opinions highlight the existence of a direct and significant nexus between tourists' activities and environmental degradation, with many implications and consequences.
\end{abstract}

Keywords: tourism activities; environmental degradation; biodiversity loss; pollution; PLS-SEM

\section{Introduction}

The nexus between tourism and the environment is very complex [1-10]. The dynamics and complexity of the nexus between tourism and the environment are due to the fact that tourism means both the multiple activities that people carry out in their leisure time-when they travel in their own country or abroad, visiting different places with a specific purpose, such as rest and relaxation, entertainment, medical treatment or to enrich their knowledge-and the industry created to satisfy all the services requested by tourists at the destination, at a high level of quality, and under the conditions of the protection and conservation of tourist resources in particular, and of the environment in general [11]. At the same time, the environment can be seen through its potential, expressed by the natural richness represented by spectacular landscapes, varied relief configuration, favourable climatic conditions, therapeutic value and the abundance of natural factors, such as mineral and thermal-mineral waters, flora and fauna [12].

From the above, it is clear that tourism largely depends on the attractiveness of the resources of the destinations [13-15] and a clean, unaltered environment cannot exist without high-quality tourism [16,17]. First of all, tourism is based on the capitalisation of these resources, but the level and intensity of this capitalisation can produce a series of negative effects on the environment in time and space [18-24], contributing to its degradation.

Globally, forests and coastal areas are the main resources used to build tourist facilities. On the one hand, forests are the natural capital and raw material of tourism; on the other 
hand, they suffer the impact of individual activities or the development of facilities associated with tourism [25]. Deforestation is one of the most important global consequences of mass tourism development on the environment, also contributing to biodiversity loss. Either by its fragmentation, destruction or the damage of habitats [26], determined by the multiplication of tourist facilities and infrastructure necessary to support them, or by the activities carried out by tourists and for tourists, such as anchoring, diving, fishing or waste, mass tourism can cause direct damage to some species or degradation of some habitats.

In addition, tourists and suppliers can introduce non-native species, which can cause enormous damage and even the destruction of entire ecosystems [19]. Even tourist hikes can cause biodiversity loss due to trampling on vegetation and soil, or tourists can stress wildlife through their observation activities or noise [26].

On the other hand, the intensification of tourism activity also generates a number of pollution effects: water pollution, noise and air pollution and aesthetic or visual pollution.

Thus, the increase in the number of tourists in certain areas and the activities undertaken by hoteliers in order to increase the quality of services and to obtain customer satisfaction cause many water pollution problems [20]. At the same time, the noise produced by the intensification of the tourist circulation represents a stress factor both for the animal species and for the local communities [27]. Tourism development also has a significant impact on air emissions in certain areas $[28,29]$ and contributes to increased air pollution, where pollution is already a stress factor for the environment [22]. At the same time, the intensification of tourist activity leads to waste increase [30], generating an aesthetic or visual pollution effect.

This paper aims to analyse the nexus between tourist activities, including tourists' circulation, accommodation or entertainment, and environmental degradation, through the effects generated by these activities. The novelty of this study is the analysis of the impact of tourism activities on biodiversity, the pollution effects generated, i.e., air, water or noise pollution, as well as the contribution to waste increase or the depletion of natural resources. To achieve these objectives, we have structured this paper in several sections, as follows: first, we provide a literature analysis, which highlights the nexuses between tourism activities and the negative effects on the environment mentioned above; then, we describe the research methodology, which includes the purpose of the research, the theoretical model at the basis of this study and the main research hypothesis, as well as information about the research tool and the data collected through it. Next, we present the results obtained from the processing of the collected data, as well as the discussion and conclusions, which include the main findings of this study, managerial implications, future research directions and research limits.

\section{Literature Review}

In general, the nexus between tourism and the environment is treated in the literature from two perspectives: either the nexus where tourism has a positive influence on the environment, contributing to its conservation [31-36], or the one where tourism is seen as a factor of environmental degradation [18,37-42], a perspective that we will also address in this paper. Consequently, there are several aspects that we will capture, as follows.

On the one hand, we analyse the impact of each tourism component included in the study, i.e., transport, accommodation and recreation, on the environment, and on the other hand, we analyse the impact of tourism activities in general on environmental degradation, i.e., on its constituent elements: land, water, air, flora and fauna. Finally, we mention some aspects of the nexus between tourism and the environment in the context of the COVID-19 pandemic.

\subsection{Impact of Tourism Components on the Environment}

Tourism transport, tourism activities performed at the level of accommodation structures, as well as tourists' recreational activities both inside and outside the accommodation structures can have a negative influence on the environment, strongly influenced by the 
intensity with which they take place in time and space. In the following, we present the impact of tourism components on the environment.

\subsubsection{Impact of Tourism Transport on the Environment}

Currently, $75 \%$ of emissions generated by tourism come from transport activity, and forecasts indicate that these will increase [43]. Transport is positively correlated with the promotion of a destination, supporting tourism and economic activity [44], but there is a clear negative impact due to traffic congestion, overcrowding, noise, air pollution and deterioration of the natural beauty of a destination [45]. It is the largest producer of $\mathrm{CO}_{2}$ emissions because air, road, rail and water transport use fossil energy sources [43,46]. Neger et al. [47] highlight this aspect by stating that emissions resulting from tourism activities are estimated at $8.1 \%$ of the total, and $49.1 \%$ are the result of transport activity. Rico et al. [48] show that $95 \%$ of emissions from tourism activities come from transport services, and air emissions are mainly responsible for pollution.

Greenhouse gas emissions from tourism transport are increasing globally, with the largest share being generated by air transport, according to Kamb et al. [49], BalsalobreLorente et al. [50], Eyuboglu and Uzar [51] and Ehigiamusoe [52].

There are analyses that capture tourism effects on the environment in a seasonal context. For example, Cavallaro et al. [43] and Seetanah and Fauzel [53] confirmed the existence of a significant nexus between climate change and short-term and long-term tourism demand. Tourism expansion increases traffic congestion, which is twice as intense in summer than in winter, with negative repercussions for the environment.

According to Budd and Ison [54], the COVID-19 pandemic was an opportunity to reconfigure transport policy for the benefit of the environment and people. As a result of the reduction in transport activity during the isolation period, there has been an improvement in air quality and a reduction in road traffic and pollution caused by air transport. The situation redirected people towards active travel, which requires physical effort, contributes to improving health and is an alternative to travel by means of transport [54,55].

Another study conducted in the context of the COVID-19 pandemic emphasises the importance of sustainable transport and tourism. Wieckowski [56] proposes changing tourists' behaviour in a "green" direction, which refers to proximity, slow travel, requiring less energy, and "green" transport.

\subsubsection{Impact of Tourist Accommodation Structures on the Environment}

The environment of tourist destinations (accommodation, natural environment, accessibility and cleanliness) is essential to provide favourable experiences for visitors [57]. The tourism sector is a constant and intensive user of natural resources. Not only does it contribute to their consumption, but it also pollutes the environment. This process occurred at the time of the emergence of hotel chains and the construction of tourist centres [58]. The expansion of the tourism industry, especially the development of the infrastructure, has had a direct impact on the environment. Excessive construction of accommodation structures, roads and airports and the use of resources as building materials for accommodation infrastructure contribute to environmental degradation [59] by clearing native forests for timber, increasing carbon use by transporting materials across long distances and cutting off routes for wildlife movement. Accommodation, an important element of the tourism sector, which also includes heating, ventilation and cooling of the rooms and the maintenance of bars, restaurants and swimming pools, has a significant share in the total $\mathrm{CO}_{2}$ emissions [48]. Accommodation structures consume a much larger amount of energy compared to the residents of a tourist destination [58]. In traditional tourist areas, power systems have not been designed to cope with the growing trend of consumption. By the end of the first decade of the 2000s, accommodation was responsible for $21 \%$ of greenhouse gases, and the services contributing to this aspect are, in particular, those with high energy intensity, such as heating and cooling of the buildings, respectively, water heating, changing of linen and towels and dining patterns, where restaurants play an important 
role [60]. According to the authors mentioned above, all these polluting activities depend on the degree of occupancy and on the classification of the accommodation unit. Regarding the latter, the highest energy consumption is recorded by 5-star hotels. In an analysis of accommodation structures in Greece, Menegaki and Agiomirgianakis [61] show that air conditioning, heating water for relaxation-less than that used for hygiene - changing linen and towels and preparing meals are activities with high energy consumption. In addition, the highest energy consumption is recorded when tourists prefer to stay in their rooms.

For many destinations, an important aspect is the management of waste from accommodation units, because their quantity exceeds the possibilities of their disposal [58].

Moreno-Luna et al. [62] noted the damage caused by the COVID-19 pandemic to both the economy in general and tourism in particular. Under the conditions of the pandemic, in Spain, it was observed that the accommodation units in rural areas were the most able to manage the situation. They offered the best options for the development of sustainable tourism, reconciling the relationship with the environment and, at the same time, offering high quality of life to residents and safety to tourists.

\subsubsection{Impact of Tourist Recreation on the Environment}

Tourism is a recreational and relaxation activity. The growing trend of the sector has led to the overcrowding of some destinations-overtourism-which affects the environment and residents, who are compelled to change their lifestyles [59]. Recreation and leisure are inextricably related to the structure of the modern human economy [63]. Leisure and recreational activities have detectable effects on the environment, mostly disturbing natural systems and wildlife and degrading biodiversity [64]. Recreational and leisure ecology covers a wide range of activities, such as camping, cycling, canoeing, skiing, diving and other water and land sports [65]. According to Giddy and Webb [66], adventure tourism has effects such as the loss of vegetation, destruction of coral reefs and increased carbon emissions. In an analysis of the impact of coastal tourism on the environment, Beeharry et al. [67] show that it consists, among others, of affecting coral reefs, increasing the amount of waste, unbalancing marine habitats, reducing biodiversity, increasing pollution and decreasing the concentration of organic matter on beaches. An analysis conducted by MacNeill and Wozniak [68] on the economic, social and environmental impact of cruise tourism highlights the increase in environmental costs for the residents of tourist areas.

There are studies highlighting the effects of the COVID-19 pandemic on tourism and recreational activity. Newsome [69] captures the economic and social impact of the COVID-19 pandemic on nature-based tourism and highlights the vulnerability of wildlife tourism in this context. Abbas et al. [70] consider that the blockage of the tourism sector derives from the increased risk of spreading the virus, especially in the first and last phase of the infectious disease. Tourism, although an important and growing industry, has shown its vulnerability. The authors of the study conclude that tourism is most affected when there are diseases, epidemics, seasonal influences and global pandemics. Recreational and leisure tourism was no exception; here, there were social and economic risks, especially bankruptcy and unemployment. Sigala [71] discusses the cessation of recreational activities around the world at the time of the pandemic. Although tourism has proved resilient in relation to other crises, such as those induced by terrorism, earthquakes, Ebola, SARS or Zika, the current one has produced long-term structural and transformational changes in time and space. The author notes that the reduction in tourism activities globally led to a reduction in pollution and in the overtourism phenomenon. Urh [63] also draws attention to the positive effect of the COVID-19 pandemic because it provided an opportunity to (re)discover outdoor recreation.

\subsection{Impact of Tourism Activities on Environmental Degradation}

Tourists' activities have a direct or indirect negative influence on the environment, and these effects will be further explained in the following section. 


\subsubsection{Impact of Tourism Activities on the Loss of Biodiversity}

Biodiversity is particularly important for the global economy and human wellbeing [72] and its loss is one of the most significant environmental problems [19], to which tourism also contributes. Consequently, a study showing the impact of tourism on biodiversity loss, conducted by Habibullah et al. [73], shows that the number of international tourist arrivals, population growth rate, protected areas and crop production increase the number of endangered species (birds, fish, mammals and plants), while an increase in GDP per capita can reduce the number of threatened species.

The results of other studies $[74,75]$ indicate that the most common recreational and tourist activities (such as hiking in the woods, camping, horseback riding), if they are not well managed, can negatively affect the value of Australian natural and semi-natural resources. In general, they can affect vegetation, which is crushed, cut or uprooted as a result of tourist activities [75], including changes in vegetation, such as loss of height, biomass, reproductive structures (flowers, fruit), reduction in cover, waste increase, damage of seedlings and alteration of the composition of species [19]. These activities lead to changes in site hydrology, soil conditions, including nutrients and erosion, as well as the introduction of invasive species. Physical effects include trace formation, soil loss and/or compaction and an increase in fire frequency.

\subsubsection{Impact of Tourism Activities on Water Pollution}

Tourism development, both by increasing the number of tourists and by the accommodation infrastructure, causes many problems related to water pollution or deterioration of its quality [20] and polluted water harms tourism, leading to a vicious cycle [76].

According to Carić and Mackelworth [77], in the case of tourist ships, water pollution can be caused by hazardous waste included in various chemicals used daily for cleaning and maintenance. Many of these liquids and materials end up in the sea due to intentional or uncontrolled spilling. At the same time, according to Butt [78], on a large cruise ship, each passenger can produce up to $40 \mathrm{~L}$ of water through the black water system and $340 \mathrm{~L}$ of grey water [79], resulting from the use of water for showers, laundry and swimming pools. Black and grey waters may also contain bacteria, viruses and pathogens, which can be hazardous to human health [80].

\subsubsection{Impact of Tourism Activities on Air Pollution}

There are a number of old or new studies $[18,21,22]$ that demonstrate the impact of tourism on air pollution by carbon dioxide emissions, and their influence on global warming and climate change. According to Walter [81], air pollution is the result of intensive tourist transport and extensive production of carbon dioxide from heating systems.

At the same time, Lenzen et al. [82] claim that the tourism industry is responsible for $8 \%$ of greenhouse gas emissions on Earth. In addition, a study conducted by Haseeb et al. [18], which used as an analytical technique the estimator method of Fully Modified Ordinary Least Squares (FMOLS) to empirically investigate the nexuses between tourism and carbon dioxide emissions for three countries in the period 1995-2015, indicates that tourism contributes substantially to carbon dioxide emissions, especially in low-income countries. Using the same method, in the case of three Asian countries (Malaysia, Thailand, Singapore), the authors Azam, Alam and Hafeez [40] reached similar results only in the case of Malaysia; for Thailand and Singapore, the results were insignificant.

Similar studies conducted by Zhang and Gao [28] for tourism in China or Katircioglu [29] for tourism in Turkey or Cyprus demonstrate the positive and statistically significant effects on carbon dioxide emissions both in the long term and in shorter periods. In addition, in the study conducted by Russo et al. [83] for tourism in Portugal, an analysis of the spatial distribution of tourist emissions was performed, emphasising that tourism had a significant impact on air emissions in certain areas (up to $40.1 \%$ ), and contributed to areas where air pollution was already a factor of environmental stress (urban centres in Porto and Lisbon). 
Another study, conducted by Gulistan, Tariq and Bashir [22], which analyses both the impact of tourism and economic growth, energy consumption and trade development on environmental degradation through carbon dioxide emissions, using annual data for the period 1995-2017, confirms that both tourism development and economic growth or energy use are harmful to the environment, proven by the existence of the environmental Kuznets curve (EKC).

According to Wang and Wang [84], tourism development will further increase carbon dioxide emissions in the future, and higher carbon dioxide emissions will have a negative impact on tourism development. The empirical results suggest, however, that an improvement in energy efficiency would benefit both tourism development and the environment.

\subsubsection{Impact of Tourism Activities on Noise Pollution}

With tourism development, anthropogenic sounds have spread throughout the biosphere, threatening both individual wellbeing and ecosystem health [85]. Thus, noise pollution has become an anthropogenic stress factor that is increasingly recognised for its negative impact [27]. Driven by the recent expansion of maritime transport, artisanal fishing and tourism (e.g., motorboats used for recreational purposes), underwater noise has greatly increased along with its negative effects [86] as well as its impact on marine species and coral reefs [87].

An interesting study conducted by Leduc et al. [85] stated that the noise recorded during the Brazilian carnival in El Salvador, which takes place annually along a coastal boulevard, increased underwater sound pressure levels by more than $30 \mathrm{~dB}$ re $1 \mu \mathrm{Pa}^{2}$, leading to changes in the behaviour of underwater species.

\subsubsection{Impact of Tourism Activities on Waste Increase}

Tourism is an important socioeconomic activity that deteriorates the quality of the ecosystem when mismanaged, increasing waste pollution [30] especially during the main tourist seasons. Plastic pollution is an essential problem of our time [88], the environmental impact of this material being obvious even in less accessible mountain areas.

A study conducted by Paiano, Crovellaand and Lagioia [89] presents an analysis of carbon dioxide emissions and waste associated with water and beverage packaging for passengers visiting Italian ports on cruise ships. Their results indicate that appropriate packaging changes can minimise waste and reduce the consumption of materials and energy resources in the packaging production cycle, thus creating environmental benefits.

\subsubsection{Impact of Tourism Activities on Depletion of Natural Resources}

The tourism industry is considered strongly associated with a large amount of water and energy consumption [90]. Thus, tourism development can put pressure on natural resources when consumption increases in areas where resources are already scarce $[23,90]$. A study conducted by Gössling et al. [24], which analyses the direct consumption of fresh water in tourism, both quantitatively and qualitatively, highlights the fact that tourism increases the global consumption of water, and proactive involvement in managing this consumption is recommended.

According to Raza et al. [42], most tourism-related activities involve energy directly in the form of fossil fuels, or indirectly in the form of electricity frequently produced from oil, coal or gas, and their consumption causes environmental degradation.

Mass tourism activity is also increasing the pressure on forests and other natural areas in Turkey [23]. Monitoring and eliminating tourism's negative impact on the environment is crucial for the protection and continuity of forest resources [25].

In conclusion, in order to improve these effects, the formulation and implementation of policy objectives oriented towards nature protection should be essential for all nexuses between the environment and tourism. 


\section{Research Methodology}

The purpose of this research consists in the assessment of the effect of tourists' activities during their travels, i.e., transport, accommodation and entertainment, on the natural environment. In order to achieve this goal, we recorded Romanian tourists' perceptions regarding environmental degradation based on a survey in which we applied questionnaires to tourists in natural tourist areas that are representative for Romania.

The questionnaire was structured in three sections, as follows: the first section included 20 items reflecting three main constructs aimed at the environmental impact of the means of transport used by tourists when traveling, the impact of their recreational activities at the destination and the impact of their accommodation behaviour in hotels. The second section included 6 items measuring tourists' perceptions of the impact of their activities on the environment, namely on biodiversity loss, air, water and noise pollution, depletion of natural resources and waste increase. The third section included the respondents' demographic data.

\subsection{Theoretical Model}

In this study, we sought to verify the existence of the influence of tourism activities on the environment according to Romanian tourists' opinions, based on a theoretical model configuring the relationships between the following constructs: tourism activities (transport, accommodation, entertainment) and the impact of tourism activities on the environment (biodiversity loss, water, air and noise pollution, waste increase, depletion of natural resources). The model proposed for validation in the research based on a statistical survey is presented in Figure 1.

The theoretical model based on the literature captures synthetically the complex relationships between tourism activities as tourism components, involving tourists' travel with various means of transport, which have an impact on the environment through the effects of the pollution that they generate $[81,86]$ or through the consumption of natural resources (fossil fuels) [42], tourists' accommodation activities that contribute to the depletion of natural resources $[23,90]$ through water and energy consumption $[42,90]$, to waste increase [30] or water pollution [20], air pollution [22,82] or noise pollution [86], as well as tourists' recreational activities that have negative consequences especially for biodiversity by its loss $[19,73]$ or degradation [75], waste increase [89] or pollution [27,87].

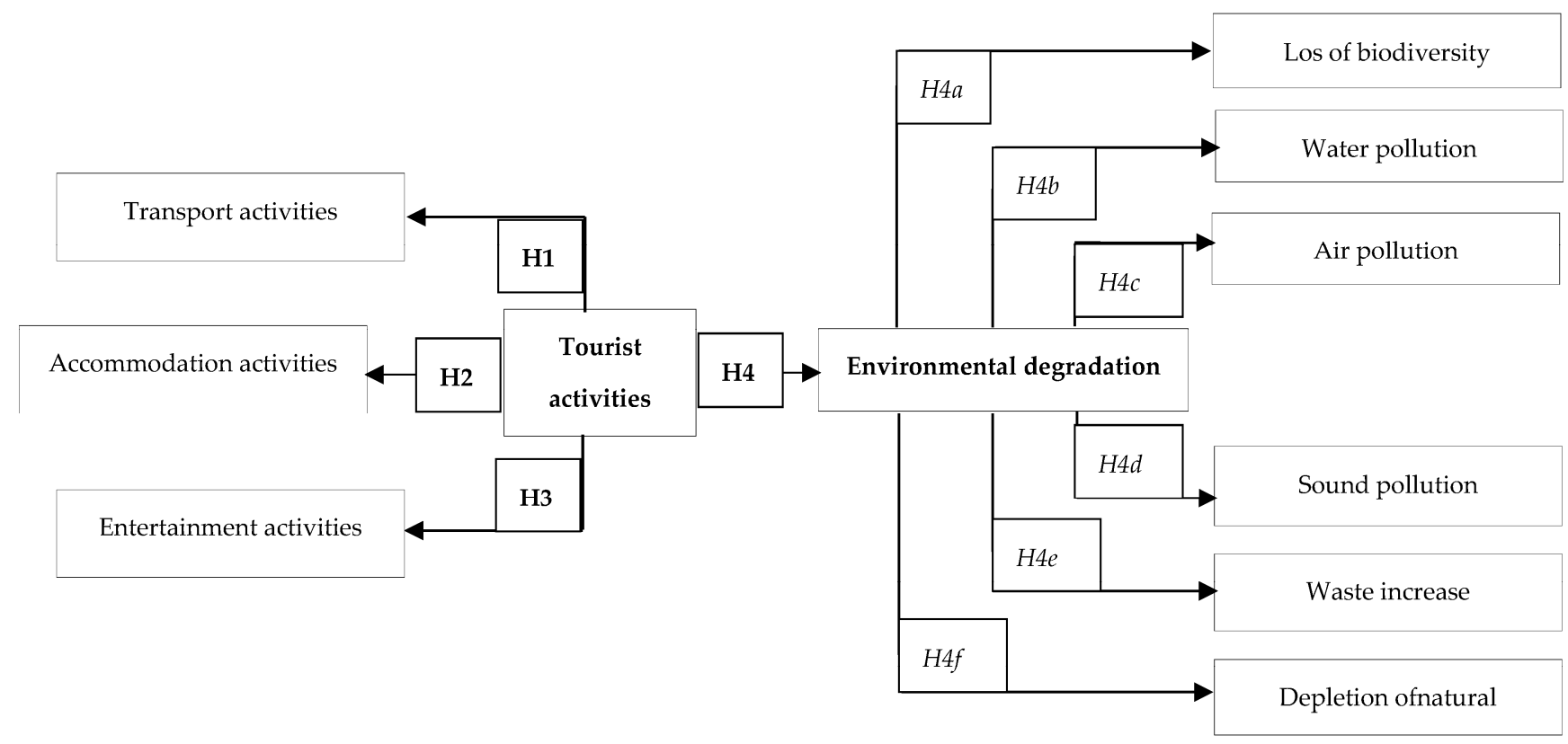

Figure 1. Theoretical model of environmental degradation. 
According to this model, the hypotheses of our study are:

Hypothesis $\mathbf{1}$ (H1). There is a direct and significant nexus between tourist transport activities and environmental degradation.

Hypothesis 2 (H2). There is a direct and significant nexus between activities involving tourists' accommodation and environmental degradation.

Hypothesis 3 (H3). There is a direct and significant nexus between tourists' recreational activities and environmental degradation.

Hypothesis 4 (H4). Tourists' activities have a direct and significant impact on environmental degradation.

Hypothesis $4 \mathbf{a}(\mathbf{H} 4 \mathbf{a})$. There is a direct and significant nexus between tourists' activities and loss of biodiversity.

Hypothesis $\mathbf{4 b} \mathbf{b} \mathbf{H} \mathbf{4 b})$. There is a direct and significant nexus between tourists' activities and water pollution.

Hypothesis $4 \mathrm{c}(\mathbf{H} 4 \mathbf{c})$. There is a direct and significant nexus between tourists' activities and air pollution.

Hypothesis $\mathbf{4 d} \mathbf{( H 4 d )}$. There is a direct and significant nexus between tourists' activities and noise pollution.

Hypothesis $4 \mathbf{e} \mathbf{( H 4 )}$. There is a direct and significant nexus between tourists' activities and waste increase.

Hypothesis $\mathbf{4 f} \mathbf{( H 4 f )}$. There is a direct and significant nexus between tourists' activities and the depletion of natural resources.

These hypotheses are justified by the direct effect of tourists' activities on the destruction of biodiversity, water, air and noise pollution, waste increase and the depletion of natural resources.

\subsection{Data and Sample}

For this study, in order to estimate and test the significance of the model of environmental degradation, data were collected through a survey. The questionnaire was designed to assess tourists' ecological behaviour and their practices related to the environment. All survey questions used a five-point Likert scale that offered a range of answer options from 1-“strongly disagree" to 5-"strongly agree". The questionnaire was pre-tested within a pilot survey on a small convenience sample in order to verify the appropriateness of the questions and to eliminate possible errors. The final sample included 203 tourists who completed the survey questionnaire concerning environmental degradation due to tourist activities. The questionnaires were filled in at the hotels where tourists were accommodated. The hotels were located in the most representative Romanian tourist destinations.

First, we processed the descriptive statistics on the collected data to assess the demographic profile of the sample. The sample structure according to a set of characteristics such as age, gender and education is presented in Table 1 . The distribution by age shows that almost a quarter of the sample consisted of young tourists under the age of 25, while more than half of the respondents were aged between 25 and 45 . According to gender, we can see that the sample structure was almost balanced. According to the level of education, the distribution of the tourists shows that most tourists had a bachelor's degree. 
Table 1. Sample structure.

\begin{tabular}{cc}
\hline Tourists' Characteristics & $\mathbf{N ~ ( \% )}$ \\
\hline Age & \\
\hline 18-25 years & $51(25.1 \%)$ \\
25-35 years & $61(30.0 \%)$ \\
35-45 years & $64(31.5 \%)$ \\
45-55 years & $21(10.3 \%)$ \\
55-65 years & $6(3.0 \%)$ \\
\hline Gender & \\
\hline Male & $97(47.8 \%)$ \\
Female & $106(52.2 \%)$ \\
\hline Education & $84(41.4 \%)$ \\
\hline High school & $91(44.8 \%)$ \\
Bachelor's degree & $28(13.8 \%)$ \\
Master's degree &
\end{tabular}

Source: Authors' calculation.

\subsection{Method}

To understand the nexus between tourist activities and environmental degradation, we applied structural equation modelling (SEM) based on partial least squares analysis (PLS) using SmartPLS (v. 3.2.7) software [91]. PLS-SEM models are path models and they are an alternative to traditional SEM, covariance-based structural equation modelling. PLS-SEM models consist of two models: (1) the measurement model relating the observable variables to their own latent variables (hypothetical constructs) - this specifies how latent variables are indicated by the observed variables; (2) the structural equation model relating some latent variables to other latent variables-this specifies the causal relationship among constructs. To test the measurement model, we applied reliability and validity analyses, while, to validate the structural model, we estimated and tested the path coefficients using a bootstrapping method [92]. The PLS technique offers the possibility to model latent constructs under the following two conditions: non-normality and small or medium sample sizes [93].

PLS-SEM has been widely applied in recent empirical tourism research $[94,95]$ for modelling the impact of tourism [96-98], ecotourism [99,100], tourist satisfaction [101] and tourist motivations [102].

In the equation system, two categories of variables are used: directly observed (measurement) variables and unobserved (latent) variables. The observed variables are supposed to be indicators of the latent variables, while there is a causal structure among latent variables.

In our study, there are four constructs corresponding to tourist activities and environmental degradation. The measurement items corresponding to each construct are presented in Table 2.

The structure of the answers on levels of the intensity of agreement on all the items corresponding to environmental degradation highlights the diversity of tourists' opinions regarding the manifestation of this phenomenon. Out of the total answers recorded for the set of items corresponding to environmental degradation, the Agree and Strongly Agree variants represent $18.52 \%$, while the Disagree and Strongly disagree variants together hold a share of $60.05 \%$, and the Neither agree or disagree variant holds $21.43 \%$ of the answers. Therefore, we can see a higher share of respondents who consider that tourists' activities have little or no effect on environmental degradation, compared to the share of those who believe that tourists' activities lead to pollution and the destruction of biodiversity. 
Table 2. Constructs and measurement items.

\begin{tabular}{cl}
\hline Transport & \\
\hline T1 & In your tourist travels, the train is the most often used means of transport. \\
T2 & In your tourist travels, the car is the most often used means of transport. \\
T3 & In your tourist travels, the plane is the most often used means of transport. \\
T4 & You are willing to replace a means of transport (plane, car) with a less polluting one (train) in your tourist travels to \\
& protect the environment. \\
T5 & Choosing the least polluting/the most environmentally friendly means of transport when traveling is an important \\
T6 & You are willing to use at the destination the local public transport or the bicycle to reduce the carbon footprint.
\end{tabular}

\begin{tabular}{cl} 
Accommodation \\
\hline A1 & If an ecological guide were offered at the destination, you would change your behaviour, paying more attention to your \\
A2 & Yourist activities and to their impact on the environment. \\
A3 & You pay special attention to the selective collection of waste at your accommodation. \\
A4 & You pay special attention to water consumption at your accommodation, making efforts not to waste water. \\
A5 & You pay special attention to energy consumption at your accommodation, making efforts to save energy. \\
A6 & You request a change of towels and linen only at the end of your stay.
\end{tabular}
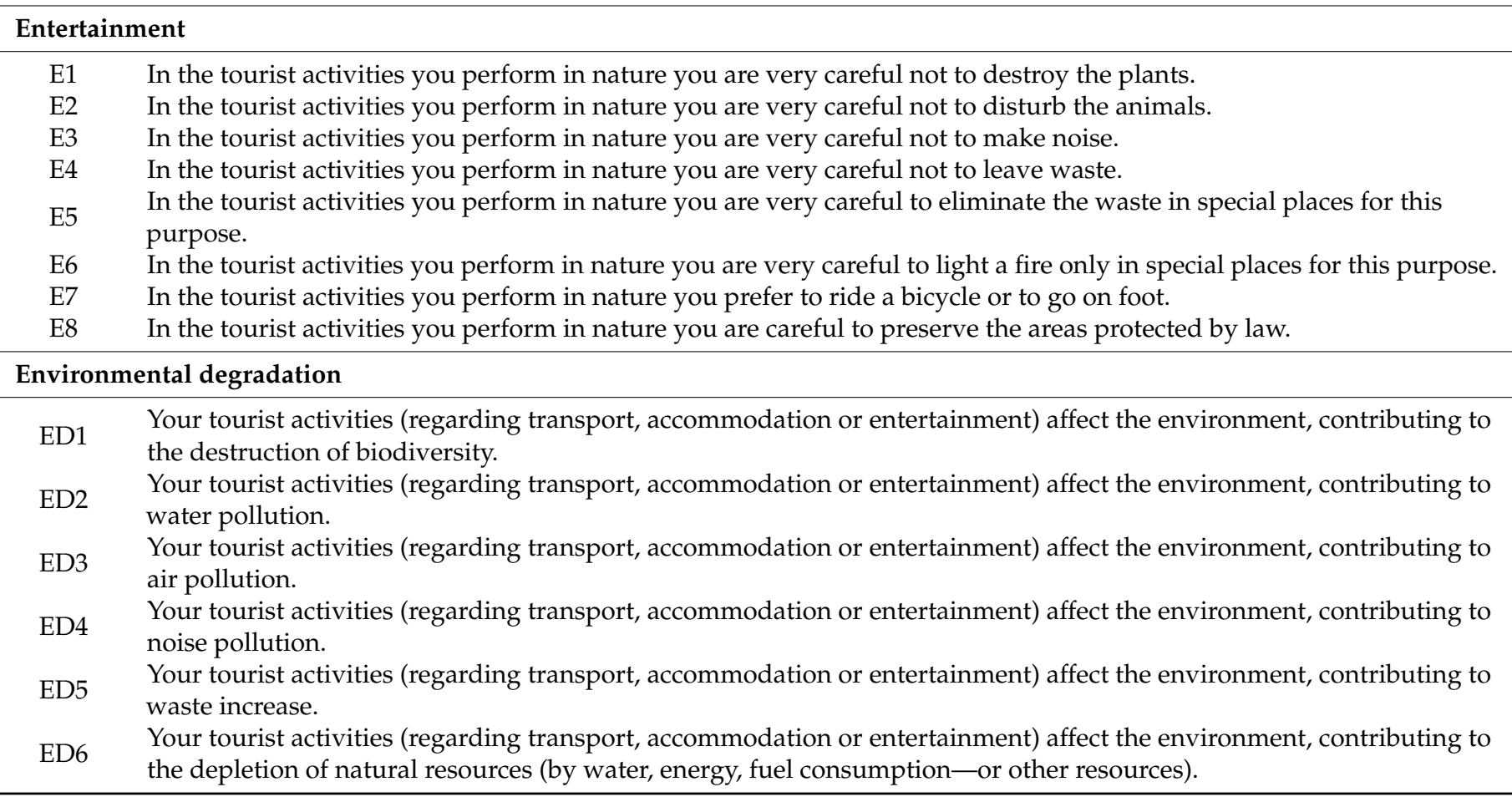

Source: Authors' definition.

The ranking of the dimensions of environmental degradation according to the share of the answers corresponding to the Agree and Strongly agree categories highlights the main negative effects of tourists' activities on environmental degradation: waste increase, air and water pollution and the depletion of natural resources (Table 3).

In order to test the model proposed in this research (Figure 1), the following three equations were estimated by the PLS-SEM method: (1) the structural equation model; (2) the measurement model for $y$; (3) the measurement model for $x[102,103]$.

$$
\begin{gathered}
\eta=\mathrm{B} \eta+\Gamma \xi+\varsigma \\
\mathrm{y}=\Lambda_{\mathrm{y}} \eta+\varepsilon \\
\mathrm{x}=\Lambda_{\mathrm{x}} \xi+\delta
\end{gathered}
$$


where $\eta$ is a random vector of latent dependent (endogenous) variables (environmental degradation); $\xi$ is a random vector of latent independent (exogenous) variables (tourist activities); $\mathrm{y}$ is a vector of observed indicators of the dependent latent variables; $\mathrm{x}$ is a vector of observed variables (indicators) of the independent latent variables; $\varepsilon$ is a vector of measurement errors in $\mathrm{y} ; \delta$ is a vector of measurement errors in $\mathrm{x} ; \Lambda_{\mathrm{y}}$ is a matrix of coefficients of the regression of $y$ on $\eta ; \Lambda_{x}$ is a matrix of coefficients of the regression of $x$ on $\xi ; \Gamma$ is a matrix of coefficients of the $\mathrm{x}$ variables in the structural model; $\mathrm{B}$ is a matrix of coefficients of the $y$ variables in the structural model; $\zeta$ is a vector of equation errors (random disturbances) in the structural model between $\eta$ and $\xi$.

Moreover, the PLS-SEM technique allows for testing of the significance of the structural path model.

Table 3. Frequency of responses for items defining environmental degradation.

\begin{tabular}{lcc}
\hline & \multicolumn{2}{c}{ Responses (\%) } \\
\cline { 2 - 3 } & Agree & Strongly Agree \\
\hline ED1-The tourist activities you perform in the environment lead to biodiversity loss. & 8.00 & 13.60 \\
ED2-The tourist activities you perform in the environment lead to water pollution. & 20.90 & 11.90 \\
ED3-The tourist activities you perform in the environment lead to air pollution. & 20.20 & 18.60 \\
ED4-The tourist activities you perform in the environment lead to noise pollution. & 9.80 & 11.90 \\
ED5-The tourist activities you perform in the environment lead to waste increase. & 28.80 & 28.80 \\
ED6-The tourist activities you perform in the environment lead to depletion of natural resources. & 12.30 & 15.30 \\
\hline Total & 100.00 & 100.00 \\
\hline
\end{tabular}

Source: Authors' definition.

\section{Results and Discussion}

The internal consistency of the constructs was tested using Cronbach's alpha. It measures the degree to which the items quantifying the same concept are in consistency [104]. We can conclude that the internal consistency is validated because all the alpha values are above 0.8 .

The measurement model was tested for convergent validity using convergent reliability and validity indicators such as Composite Reliability (CR) and Average Variance Extracted (AVE) [92].

In order to assess the extent to which the construct indicators represent the latent construct, we computed the Composite Reliability indicator. To measure the amount of variance in the indicators accounted for by the latent construct, we obtained the Average Variance Extracted. Table 4 presents the convergent reliability and validity indicators. For all the constructs, we can see that the $C R$ values surpass the recommended value of 0.7 , and all AVE values exceed the recommended value of 0.5 . Therefore, the results on the measurement model indicate an adequate level of convergent reliability and validity.

Table 4. Convergent reliability and validity.

\begin{tabular}{lcccc}
\hline $\begin{array}{c}\text { Construct (The Model of } \\
\text { Environmental Degradation) }\end{array}$ & $\begin{array}{c}\text { Cronbach's } \\
\text { Alpha }\end{array}$ & rho_A & $\begin{array}{c}\text { Composite Reliability } \\
\text { (CR) }\end{array}$ & $\begin{array}{c}\text { Average Variance } \\
\text { Extracted (AVE) }\end{array}$ \\
\hline Transportation & 0.882 & 0.927 & 0.913 & 0.653 \\
Accommodation & 0.875 & 0.962 & 0.917 & 0.679 \\
Entertainment & 0.922 & 0.972 & 0.948 & 0.720 \\
\hline Tourist activities & 0.942 & 0.972 & 0.953 & 0.538 \\
\hline Environmental degradation & 0.942 & 0.999 & 0.965 & 0.835 \\
\hline
\end{tabular}

Source: Authors' calculation with SmartPLS (v. 3.2.7) software. 
We can conclude that the measurement items are good indicators of the four constructs of the model relating tourist activities to environmental degradation.

Considering the main findings of the literature review and based on the research model (Figure 1), we aimed to find the nexus between tourist activities and environmental degradation in Romania. Figure 2 shows the coefficients of the final structural equation model estimated using the PLS analysis.

The path coefficient "Tourist activities -> Environmental degradation" is equal to 0.886 and shows that tourist activities have a direct effect on environmental degradation. At the same time, tourist activities are explained by the three components: transportation, accommodation and recreation. For these relationships, the path coefficients are positive, and the highest value corresponds to the coefficient reflecting the recreational dimension of tourist activities.

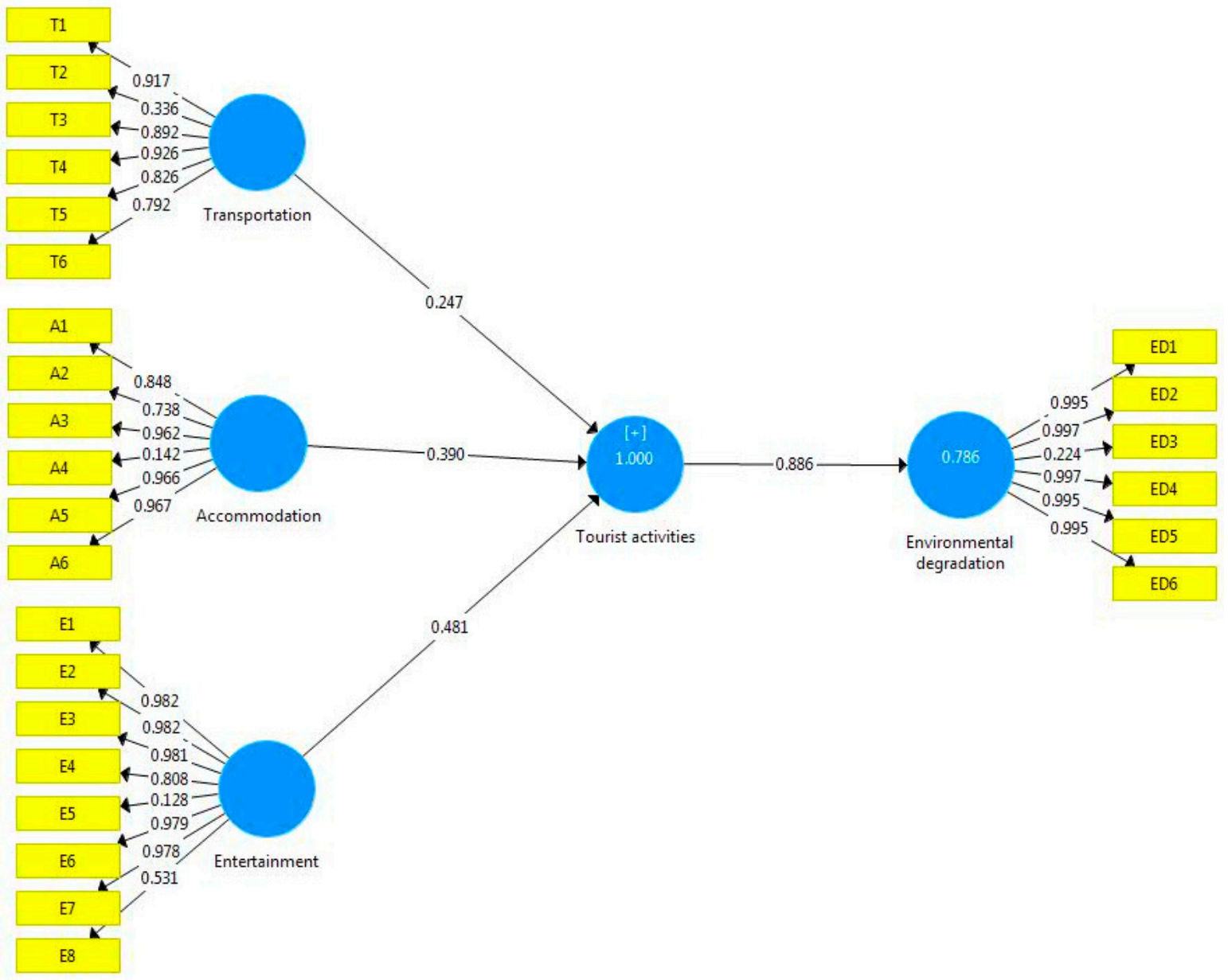

Figure 2. Structural model, Source: Authors' calculation with SmartPLS (v. 3.2.7) software.

To assess the structural model, the bootstrapping procedure was used to verify the significance levels of path coefficients [92]. Therefore, the hypothesised relationships in the structural model were tested.

Table 5 shows that the path coefficients between the constructs in the model are significant, as indicated by the corresponding $\mathrm{t}$-values via the bootstrapping procedure. These results show strong support for the hypothesis of this study. The path coefficient "Tourist activities $->$ Environmental degradation" is highly significant (t-value $=2.018$; $p$-value $<0.05)$. Thus, the main hypothesis is supported by the data, and the structural model is significant. 
Table 5. Testing the significance of path coefficients.

\begin{tabular}{llccc}
\hline & \multicolumn{1}{c}{ Relationships } & Path Coefficient & T Statistics & $\begin{array}{c}\text { Is the Hypothesis } \\
\text { Supported? }\end{array}$ \\
\hline H1 & Transportation -> Tourist activities & $0.247^{*}$ & 1.766 & YES \\
H2 & Accommodation -> Tourist activities & $0.390^{* *}$ & 2.447 & YES \\
H3 & Entertainment - Tourist activities & $0.481^{* * *}$ & 4.763 & YES \\
H4 & Tourist activities - $>$ Environmental degradation & $0.886^{* *}$ & 2.018 & YES \\
\hline
\end{tabular}

Note: ${ }^{* * *} p$ value $<0.01,{ }^{* *} p$ value $<0.05,{ }^{*} p$ value $<0.1$; Source: Authors' calculation with SmartPLS (v. 3.2.7) software.

The results in Table 5 and Figure 2 reveal that the path coefficients are above the recommended value of 0.1 [105]. Moreover, the combination of tourist activities explains $78.6 \%$ of variance in environmental degradation ( $\mathrm{R}$ Squared $=0.786$ ). To summarize, according to tourists' opinions, in Romania, tourist activities have a strong effect on environmental degradation. Therefore, we can conclude, based on the statistical results obtained through the PLS-SEM method, that the four hypotheses of this research have been validated.

More explicitly, the results state that the activities performed to ensure tourists' travel to tourist destinations, also between their accommodation and meals and tourist attractions or other facilities specific to tourism, have a negative impact on the environment, as demonstrated by Kanwal et al. [45] as well. Thus, heavy traffic, overcrowding and noise or air pollution have a negative influence on the environment in these destinations. In addition, the means of transport used by tourists, mainly by air or by car, prove to be most harmful to the environment through the emission of carbon dioxide or other substances $[43,47,48]$. This situation could be improved if tourists were willing to give up the comfort offered by fast means of transport and choose other means of transport, which are more environmentally friendly, a conclusion reached also by the authors Kamb et al. [49] and Ehigiamusoe [52], or at least to use local public transport to reach their destination. Even choosing tourist destinations closer to tourists' place of residence can be a solution to reduce the carbon footprint, as suggested by Wieckowski [56].

Regarding the tourist activities performed at the level of accommodation structures, they have a direct impact on the environment, which is strongly influenced by their intensity in time and space. Thus, the intensive use of water in the accommodation sector and the supply and use of energy resources contribute to the depletion of natural resources and also to the degradation and destruction of vegetation, air pollution and waste. Similar results are highlighted by Rico et al. [48] and Gőssling and Lund-Durlacher [60], who demonstrate the contribution of the accommodation sector to the intensification of air pollution through the generated carbon dioxide emissions. The results obtained by Rico et al. [48], Pobihun et al. [58] and Menegaki and Agiomirgianakis [61] present the accommodation activity as highly resource-consuming and highly waste-generating [58]. All these studies show that the accommodation sector is responsible, to a greater or lesser extent, for environmental degradation. At the same time, tourists' indifference, proven by their lack of involvement or by the fact that they do not want to minimise their carbon footprint by paying eco taxes at the destination, indirectly contributes to environmental degradation. According to Warren et al. [106], increasing tourists' ecological responsibility and adopting environmentally friendly behaviour can be solutions to improve the nexus between tourism and the environment.

Regarding recreational activities, the results indicate that tourists contribute to the disruption of the natural ecosystem, by destroying plants or disturbing wildlife, as emphasised by Naidoo and Burton [64] or Giddy and Webb [66]. At the same time, as also shown by Beeharry et al. [67], recreational activities contribute greatly to the increase in waste and pollution. Most of the time, tourists leave garbage behind, or they do not place it in specially designed places. Moreover, they do not even take into account the tourist areas protected by law, where they are required to adopt appropriate behaviour. According to Yi and Tsung [107], the solution to reduce the impact of recreational activities on the 
environment is mainly responsible human behaviour. Only in this way can the nexus between tourism and the environment be improved, and the tourist activities, whether they involve travel, accommodation or tourists' recreation, will no longer have such an intense impact on environmental degradation.

\section{Conclusions, Future Research Directions and Limits}

From a theoretical point of view, the results of this study contribute to the improvement of the understanding of tourism factors/activities leading to biodiversity loss, air, water or noise pollution, waste increase or the depletion of natural resources. At the same time, although there are several research works [1-10] focusing on the nexus between tourism and the environment, no known work has investigated this relationship from the perspective of tourists and according to the three important components of tourism, i.e., transport, accommodation and entertainment, or from the Romanian perspective. Therefore, we believe that this study adds value to the literature.

The practical implication of the study is to provide recommendations to all those involved in tourism activities, either tourists or tourism operators, local communities, suppliers or authorities, to encourage more attention to tourism activities, so as to bring less harm to the environment. Thus, this study tries to understand tourists' attitudes and perspectives by the influence of the constructs of the three components of tourism activities on environmental degradation, because these findings can be valuable for the suppliers of transport, accommodation and entertainment services, as well as for local or national policymakers in terms of the effective implementation of environmental strategies for tourist destinations.

This is particularly important, because trends and forecasts show that, along with the continuous expansion of the tourism sector, its negative effects will amplify in the coming years. In the event of a change in the current state of affairs, the tourism growth rate forecasted by 2050 will involve an increase in energy consumption by 154\%, in greenhouse gas emissions by $131 \%$, in water consumption by $152 \%$ and in solid waste by $251 \%$ [108].

Consequently, the results of this study highlight the fact that tourists' activities during their travels have a significant impact on environmental degradation, which will continue to increase if no action is taken and if the behaviour of absolutely all entities involved in tourism and of others does not change.

The development of tourism and of its associated activities does not have only positive effects; it also affects the quality of the environment through traffic congestion, overexploitation of natural resources and problems generated by inappropriate tourism behaviours [109]. In addition, the development of the tourism sector requires massive investments in infrastructure, such as roads, airports and various tourist services (shops, resorts, restaurants and hotels) [110]. Therefore, it is not surprising that tourism can place a heavy burden on the environment [111] and this can also be seen from our study. Thus, the three components of tourism activities, namely transport, accommodation and entertainment, were significantly and positively correlated with tourism activities leading to environmental degradation. In this regard, the study confirmed and validated the nexus between tourism activities and environmental degradation.

Regarding future research directions, it would be interesting and important to extend this study taking into account other variables. At the same time, we could analyse the relationship in which tourism has a positive influence on the natural environment, contributing to its conservation. The approach to the nexus between tourism and the environment can also be considered from the perspective of tourist service suppliers, modelling the nexus between their activities in order to obtain tourists' satisfaction and the impact on the environment or the contribution to its protection. 
Author Contributions: Conceptualisation, M.Ș., C.B.S., G.I.B. and A.-P.H.; methodology, M.Ș. and C.B.S.; software, C.B.S.; validation, M.Ș. and C.B.S.; formal analysis, M.S., C.B.S., G.I.B. and A.-P.H.; investigation, M.Ș.; resources, M.S., C.B.S., G.I.B. and A.-P.H.; data curation, M.Ș., C.B.S., G.I.B. and A.-P.H.; writing-original draft preparation, M.S., C.B.S., G.I.B. and A.-P.H.; writing-review and editing, M.S,., C.B.S., G.I.B. and A.-P.H.; visualisation, M.S., C.B.S., G.I.B. and A.-P.H.; supervision, M.S., C.B.S., G.I.B. and A.-P.H.; project administration, M.S., C.B.S., G.I.B. and A.-P.H.; funding acquisition, M.S., C.B.S., G.I.B. and A.-P.H. All authors have read and agreed to the published version of the manuscript.

Funding: This research received no external funding.

Institutional Review Board Statement: Not applicable.

Informed Consent Statement: Not applicable.

Data Availability Statement: Not applicable.

Acknowledgments: This work was supported by a grant from the Romanian Ministry of Education and Research, CNCS-UEFISCDI, project number PN-III-P1-1.1-TE-2019-1642, within PNCDI III.

Conflicts of Interest: The authors declare no conflict of interest.

\section{References}

1. Tang, Z. An integrated approach to evaluating the coupling coordination between tourism and the environment. Tour. Manag. 2015, 46, 11-19. [CrossRef]

2. Hall, D.R. Evaluating the tourism-Environment relationship: Central and East European experiences. Environ. Plan. B Plan. Des. 2000, 27, 411-421. [CrossRef]

3. Butler, R.W. Tourism and the environment: A geographical perspective. Tour. Geogr. 2000, 2, 337-358. [CrossRef]

4. Ouattara, B.; Pérez-Barahona, A.; Strobl, E. Dynamic implications of tourism and environmental quality. J. Public Econ. Theory 2019, 21, 241-264. [CrossRef]

5. Danish; Wang, z. Dynamic relationship between tourism, economic growth, and environmental quality. J. Sustain. Tour. 2018, 26, 1928-1943. [CrossRef]

6. Ozturk, I. The relationships among tourism development, energy demand, and growth factors in developed and developing countries. Int. J. Sustain. Dev. World Ecol. 2016, 23, 122-131. [CrossRef]

7. Mohanty, P.; Chandran, A.; Swain, N. Promoting Gender Sensitivity and Environment Protection through Sustainable Tourism Development: A Review. J. Tour. 2018, 19, 87.

8. Romeril, M. Tourism and the environment-Towards a symbiotic relationship: (Introductory paper). Int. J. Environ. Stud. 1985, 25, 215-218. [CrossRef]

9. Tisdell, C. Globalisation and sustainability: Environmental Kuznets curve and the WTO. Ecol. Econ. 2001, 39, 185-196. [CrossRef]

10. Rey-Maquieira, J.; Lozano, J.; Gomez, C.M. Quality standards versus taxation in a dynamic environmental model of a tourism economy. Environ. Model. Softw. 2009, 24, 1483-1490. [CrossRef]

11. Netto, A.P. What is tourism? Definitions, theoretical phases and principles. Philos. Issues Tour. 2009, 37, 43-62. [CrossRef]

12. Schaeffer, Y.; Dissart, J.C. Natural and environmental amenities: A review of definitions, measures and issues. Ecol. Econ. 2018, 146, 475-496. [CrossRef]

13. Cracolici, M.F.; Nijkamp, P. The attractiveness and competitiveness of tourist destinations: A study of Southern Italian regions. Tour. Manag. 2009, 30, 336-344. [CrossRef]

14. Vengesayi, S.; Mavondo, F.T.; Reisinger, Y. Tourism destination attractiveness: Attractions, facilities, and people as predictors. Tour. Anal. 2009, 14, 621-636. [CrossRef]

15. Dapkus, R.; Dapkute, K. Evaluation of the Regional Tourism Attractiveness. Res. Rural Dev. 2015, 2, 293-300. Available online: https:/ /llufb.llu.lv / conference/Research-for-Rural-Development/2015/LatviaResearchRuralDevel21st_volume2-293 -300.pdf (accessed on 20 April 2021).

16. Green, H.; Hunter, C. The environmental impact assessment of tourism development. Perspect. Tour. Policy 1992, 29-47. Available online: https:/ / www.cabdirect.org/cabdirect/abstract/19921896476 (accessed on 15 April 2021).

17. Sghaier, A.; Guizani, A.; Jabeur, S.B.; Nurunnabi, M. Tourism development, energy consumption and environmental quality in Tunisia, Egypt and Morocco: A trivariate analysis. GeoJournal 2019, 84, 593-609. [CrossRef]

18. Haseeb, M.; Hassan, S.; Azam, M.; Suryanto, T. The dynamics of governance, tourism and environmental degradation: The world evidence. Int. J. Glob. Environ. Issues 2018, 17, 340-363. [CrossRef]

19. Hall, C.M. Tourism and biodiversity: More significant than climate change? J. Herit. Tour. 2010, 5, 253-266. [CrossRef]

20. Baoying, N.; Yuanqing, H. Tourism development and water pollution: Case study in Lijiang Ancient Town. China Popul. Resour. Environ. 2007, 17, 123-127. [CrossRef] 
21. Sharif, A.; Godil, D.I.; Xu, B.; Sinha, A.; Khan, S.A.R.; Jermsittiparsert, K. Revisiting the role of tourism and globalization in environmental degradation in China: Fresh insights from the quantile ARDL approach. J. Clean. Prod. 2020, $272,122906$. [CrossRef]

22. Gulistan, A.; Tariq, Y.B.; Bashir, M.F. Dynamic relationship among economic growth, energy, trade openness, tourism, and environmental degradation: Fresh global evidence. Environ. Sci. Pollut. Res. 2020, 27, 13477-13487. [CrossRef] [PubMed]

23. Gedik, S.; Mugan-Ertugral, S. The effects of marine tourism on water pollution. Fresenius Environ. Bull 2019, 28, 863-866. Available online: https: / / www.cabdirect.org/cabdirect/abstract/20193484954 (accessed on 7 March 2021).

24. Gössling, S.; Peeters, P.; Hall, C.M.; Ceron, J.P.; Dubois, G.; Scott, D. Tourism and water use: Supply, demand, and security. An international review. Tour. Manag. 2012, 33, 1-15. [CrossRef]

25. Kuvan, Y. Mass tourism development and deforestation in Turkey. Anatolia 2010, 21, 155-168. [CrossRef]

26. Choi, Y.E.; Song, K.; Kim, M.; Lee, J. Transformation planning for resilient wildlife habitats in ecotourism systems. Sustainability 2017, 9, 487. [CrossRef]

27. Nikolich, K.; Halliday, W.D.; Pine, M.K.; Cox, K.; Black, M.; Morris, C.; Juanes, F. The sources and prevalence of anthropogenic noise in Rockfish Conservation Areas with implications for marine reserve planning. Mar. Pollut. Bull. 2021, $164,112017$. [CrossRef] [PubMed]

28. Zhang, L.; Gao, J. Exploring the effects of international tourism on China's economic growth, energy consumption and environmental pollution: Evidence from a regional panel analysis. Renew. Sustain. Energy Rev. 2016, 53, 225-234. [CrossRef]

29. Katircioglu, S.T. International tourism, energy consumption, and environmental pollution: The case of Turkey. Renew. Sustain. Energy Rev. 2014, 36, 180-187. [CrossRef]

30. Garcés-Ordóñez, O.; Castillo-Olaya, V.A.; Granados-Briceño, A.F.; García, L.M.B.; Díaz, L.F.E. Marine litter and microplastic pollution on mangrove soils of the Ciénaga Grande de Santa Marta, Colombian Caribbean. Mar. Pollut. Bull. 2019, 145, 455-462. [CrossRef]

31. Anup, K.C. Tourism and its role in environmental conservation. J. Tour. Hosp. Educ. 2018, 8, 30-47.

32. Rastegar, R. Tourism development and conservation, do local resident attitudes matter? Int. J. Tour. Sci. 2019, 19, 181-191. [CrossRef]

33. Pérez-Jorge, S.; Gomes, I.; Hayes, K.; Corti, G.; Louzao, M.; Genovart, M.; Oro, D. Effects of nature-based tourism and environmental drivers on the demography of a small dolphin population. Biol. Conserv. 2016, 197, 200-208. [CrossRef]

34. Souza, G.D.; Dabezies, J.M. Tourism development and environmental conservation: Tensions in the protected landscape of Lunarejo Valley, Uruguay. ROSA DOS VENTOS-Tur. E Hosp. 2019, 11, 253-268. [CrossRef]

35. Walpole, M.; Goodwin, H. Local attitudes towards conservation and tourism around Komodo National Park, Indonesia. Environ. Conserv. 2001, 28, 160-166. [CrossRef]

36. Zhang, Y.L.; Zhang, J.; Zhang, H.O.; Zhang, R.Y.; Wang, Y.; Guo, Y.R.; Wei, Z.C. Residents' environmental conservation behaviour in the mountain tourism destinations in China: Case studies of Jiuzhaigou and Mount Qingcheng. J. Mt. Sci. 2017, 14, $2555-2567$. [CrossRef]

37. Lukashina, N.S.; Amirkhanov, M.M.; Anisimov, V.I.; Trunev, A. Tourism and environmental degradation in Sochi, Russia. Ann. Tour. Res. 1996, 23, 654-665. [CrossRef]

38. Zanetto, G.; Soriani, S. Tourism and environmental degradation: The Northern Adriatic Sea. Sustain. Tour. Eur. Exp. 1996, 137-152. Available online: https://www.cabdirect.org/cabdirect/abstract/19961807091 (accessed on 25 April 2021).

39. Ahmad, F.; Draz, M.U.; Su, L.; Rauf, A. Taking the bad with the good: The nexus between tourism and environmental degradation in the lower middle-income Southeast Asian economies. J. Clean. Prod. 2019, 233, 1240-1249. [CrossRef]

40. Azam, M.; Alam, M.M.; Hafeez, M.H. Effect of tourism on environmental pollution: Further evidence from Malaysia, Singapore and Thailand. J. Clean. Prod. 2018, 190, 330-338. [CrossRef]

41. Ahmad, F.; Draz, M.U.; Su, L.; Ozturk, I.; Rauf, A. Tourism and Environmental Pollution: Evidence from the One Belt One Road Provinces of Western China. Sustainability 2018, 10, 3520. [CrossRef]

42. Raza, S.A.; Sharif, A.; Wong, W.K.; Karim, M.Z.A. Tourism development and environmental degradation in the United States: Evidence from wavelet-based analysis. Curr. Issues Tour. 2017, 20, 1768-1790. [CrossRef]

43. Cavallaro, F.; Galati, O.I.; Nocera, S. Climate change impacts and tourism mobility: A destination-based approach for costal areas. Int. J. Sustain. Destin. 2020, 15, 456-473. [CrossRef]

44. Spasojevic, B.; Lohmann, G.; Scott, N. Air transport and tourism-A systematic literature review (2000-2014). Curr. Issues Tour. 2018, 21, 975-997. [CrossRef]

45. Kanwal, S.; Rasheed, I.M.; Pitafi, A.H.; Pitafi, A.; Ren, M. Road and Transport infrastructure development and community support for tourism: The role of perceived benefits, and community satisfaction. Tour. Manag. 2020, 77, 104014. [CrossRef]

46. Koçak, E.; Ulucak, R.; Ulucak, Z.S. The impact of tourism development on $\mathrm{CO}_{2}$ emissions: An advanced panel data estimation. Tour. Manag. Perspect. 2020, 33, 100611. [CrossRef]

47. Neger, C.; Prettenthaler, F.; Gössling, S.; Damm, S. Carbon intensity of tourism in Austria: Estimates and policy implication. J. Outdoor Recreat. Tour. 2021, 33, 100311. [CrossRef]

48. Rico, A.; Martinez-Blanco, J.; Mont Meó, M.; Rodriguez, G.; Tavares, N.; Arias, A.; Oliver-Solà, J. Carbon footprint of tourism in Barcelona. Tour. Manag. 2019, 70, 491-504. [CrossRef] 
49. Kamb, A.; Lundberg, E.; Larsson, J.; Nilsson, J. Potentials for reducing climate impact from tourism transport behaviour. J. Sustain. Tour. 2021, 29, 1365-1382. [CrossRef]

50. Balsalobre-Lorente, D.; Driha, O.M.; Bekun, F.V.; Adedoyin, F.F. The Asymetric impact of air transport on economic growth in Spain: Fresh evidence from tourism-led growth hypothesis. Curr. Issues Tour. 2021, 24, 503-519. [CrossRef]

51. Eyuboglu, K.; Uzar, U. The impact of tourism on $\mathrm{CO}_{2}$, emission in Turkey. Curr. Issues Tour. 2019, 23, 659-665. [CrossRef]

52. Ehigiamusoe, K.U. Tourism, growth and environment: Analysis of non-linear and moderating effects. J. Sustain. 2020, 28, 1174-1192. [CrossRef]

53. Seetanah, B.; Fouzel, S. Investigating the impact of climate change on the tourism sector: Evidence from a sample of island economies. Tour. Rev. 2018, 74, 194-203. [CrossRef]

54. Budd, L.; Ison, S. Responsible transport: A post-COVID agenda for transport policy and practice. Transp. Res. Interdiscip. Perspect. 2020, 6, 100151. [CrossRef] [PubMed]

55. Šebešová, A.; Kršák, B. Notes on the impact of cycling infrastructure on tourist destination management. Acta Geoturistica 2018, 9 , 24-27. [CrossRef]

56. Wieckowski, M. Will the consequences of COVID-19 trigger a redefining of the role of transport in the development of sustainable tourism? Sustainability 2021, 13, 1887. [CrossRef]

57. Voon, B.H.; Hamali, J.; Jussem, P.M.; Teo, A.K.; Kanyan, A. Socio-Environmental Dimensions of Tourism Service Experience in Homestays. Int. J. Geomate 2017, 12, 96-100. [CrossRef]

58. Pobihun, O.; Korobeinykova, Y.; Nykodiuk, O.; Melnyk, A. Mechanisms for Ensuring the Environmental Safety of Tourist Destinations. In Proceedings of the Second International Conference on Sustainable Futures: Environmental, Technological, Social and Economic Matters (ICSF 2021), Kryvyi Rih, Ukraine, 12-21 May 2021; Volume 280. [CrossRef]

59. Sarantakou, E.; Terkenli, T.S. Non-Institutionalized Forms of Tourism Accommodation and Overtourism Impacts on the Landscape: The Case of Santorini, Greece. Tour. Plan. Dev. 2019, 16, 411-433. [CrossRef]

60. Gössling, S.; Lund-Durlacher, D. Tourist accommodation, climate change and mitigation: An assessment for Austria. J. Outdoor Recreat. Tour. 2021, 100367. [CrossRef]

61. Menegaki, A.N.; Agiomirgianakis, G.M. Sustainable Technologies in Greek Tourist Accommodation: A Quantitative Review. Eur. Res. Stud. J. 2018, 21, 222-238. [CrossRef]

62. Moreno-Luna, L.; Robina-Ramírez, R.; Sánchez, M.S.-O.; Castro-Serrano, J. Tourism and Sustainability in Times of COVID-19: The Case of Spain. Int. J. Environ. Res. Public Health 2021, 18, 1859. [CrossRef] [PubMed]

63. Urh, B. The Impact of leisure and tourism on public health in pandemic times. Quaestus 2021, 18, 84-95. Available online: https://www.quaestus.ro/wp-content/uploads/2012/03/Barbara-Uhr2.pdf (accessed on 5 July 2021).

64. Naidoo, R.; Burton, A.C. Relative effects of recreational activities on a temperate terrestrial wildlife assemblage. Conserv. Sci. Pract. 2020, 2, e271. [CrossRef]

65. Sumanapala, D; Wolf, I.D. Recreational Ecology: A Review of Research and Gap Analysis. Environments 2019, 6, 81. [CrossRef]

66. Giddy, J.K.; Webb, N.L. The influence of the environment on adventure tourism: From motivations to experiences. Curr. Issues Tour. 2016, 21, 2132-2146. [CrossRef]

67. Beeharry, Y.; Bekaroo, G.; Bussoopun, D.; Bokhoree, C.; Phillips, M.R. Perspectives of leisure operators and tourists on the environmental impacts of coastal tourism activities: A case study Mauritius. Environ. Dev. Sustain. 2021, 23, 10702-10726. [CrossRef]

68. MacNeill, T.; Wozniak, D. The economic, social, and environmental impacts of cruise tourism. Tour. Manag. 2018, 66, 387-404. [CrossRef]

69. Newsome, D. The collapse of tourism and its impact on wildlife tourism destinations. J. Tour. Futures 2020. Available online: https://www.emerald.com/insight/content/doi/10.1108/JTF-04-2020-0053/full/html (accessed on 14 August 2021). [CrossRef]

70. Abbas, J.; Mubeen, R.; Iorember, P.T.; Raza, S. Exploring the impact of COVID-19 on tourism: Transformational potential and implications for a sustainable recovery of the travel and leisure industry. Curr. Res. Behav. Sci. 2021, 2, 100033. [CrossRef]

71. Sigala, M. Tourism and COVID-19: Impacts and implications for advancing and resetting industry and research. J. Bus. Res. 2020, 117, 312-321. [CrossRef] [PubMed]

72. Martens, P.; Rotmans, J.; de Groot, D. Biodiversity: Luxury or necessity? Glob. Environ. Chang. 2003, 13, 75-81. [CrossRef]

73. Habibullah, M.S.; Din, B.; Chong, C.W.; Radam, A. Tourism and biodiversity loss: Implications for business sustainability. Procedia Econ. Financ. 2016, 35, 166-172. [CrossRef]

74. Sun, D.; Walsh, D. Review of studies on environmental impacts of recreation and tourism in Australia. J. Environ. Manag. 1998, 53, 323-338. [CrossRef]

75. Pickering, C.M.; Hill, W. Impacts of recreation and tourism on plant biodiversity and vegetation in protected areas in Australia. J. Environ. Manag. 2007, 85, 791-800. [CrossRef] [PubMed]

76. Wang, Q.; Zhang, J.; Ding, Z.; Yang, X. Review of oversea studies on tourism impact of water environment. Prog. Geogr. 2005, 1, 127-136. Available online: https://en.cnki.com.cn/Article_en/CJFDTotal-DLKJ200501014.htm (accessed on 7 July 2021).

77. Carić, H.; Mackelworth, P. Cruise tourism environmental impacts-The perspective from the Adriatic Sea. Ocean Coast. Manag. 2014, 102, 350-363. [CrossRef]

78. Butt, N. The impact of cruise ship generated waste on home ports and ports of call: A study of Southampton. Mar. Policy 2007, 31, 591-598. [CrossRef] 
79. Klein, R.A. Responsible cruise tourism: Issues of cruise tourism and sustainability. J. Hosp. Tour. Manag. 2011, 18, 107-116. [CrossRef]

80. Kay, B.H. A State of the Environment Report: Pollutants in British Columbia's Marine Environment: A status report. Ott. Environ. Can. 1989, 89, 1-62. Available online: https://publications.gc.ca/collections/collection_2020/eccc/En1-11-89-1-eng.pdf (accessed on 25 April 2021).

81. Walter, S. Climate change and the skiing industry: Impacts and potential responses. Res. Semin. Arct. Stud. Program. 2001. Available online: http:/ / kaares.ulapland.fi/home/hkunta/jmoore/climateskiing.pdf (accessed on 18 September 2017).

82. Lenzen, M.; Sun, Y.Y.; Faturay, F.; Ting, Y.P.; Geschke, A.; Malik, A. The carbon footprint of global tourism. Nat. Clim. Chang. 2018, 8, 522-528. [CrossRef]

83. Russo, M.; Relvas, H.; Gama, C.; Lopes, M.; Borrego, C.; Rodrigues, V.; Robaina, M.; Madaleno, M.; Carneiro, M.; Eusébio, C.; et al. Estimating emissions from tourism activities. Atmos. Environ. 2020, 220, 117048. [CrossRef]

84. Wang, M.C.; Wang, C.S. Tourism, the environment, and energy policies. Tour. Econ. 2018, 24, 821-838. [CrossRef]

85. Leduc, A.O.; Nunes, J.A.C.; de Araújo, C.B.; Quadros, A.L.; Barros, F.; Oliveira, H.H.; Simões, C.R.M.; Winandy, G.S.; Slabbekoorn, H. Land-based noise pollution impairs reef fish behavior: A case study with a Brazilian carnival. Biol. Conserv. 2021, 253, 108910. [CrossRef]

86. Vakili, S.V.; Ölçer, A.I.; Ballini, F. The development of a policy framework to mitigate underwater noise pollution from commercial vessels: The role of ports. Mar. Policy 2020, 120, 104132. [CrossRef]

87. Ferrier-Pagès, C.; Leal, M.C.; Calado, R.; Schmid, D.W.; Bertucci, F.; Lecchini, D.; Allemand, D. Noise pollution on coral reefs?-A yet underestimated threat to coral reef communities. Mar. Pollut. Bull. 2021, 165, 112129. [CrossRef] [PubMed]

88. Napper, I.E.; Davies, B.F.; Clifford, H.; Elvin, S.; Koldewey, H.J.; Mayewski, P.A.; Miner, K.R.; Potocki, M.; Elmore, A.C.; Gajurel, A.P.; et al. Reaching new heights in plastic pollution-Preliminary findings of microplastics on Mount Everest. One Earth 2020, 3 , 621-630. [CrossRef]

89. Paiano, A.; Crovella, T.; Lagioia, G. Managing sustainable practices in cruise tourism: The assessment of carbon footprint and waste of water and beverage packaging. Tour. Manag. 2020, 77, 104016. [CrossRef]

90. Lee, L.C.; Wang, Y.; Zuo, J. The nexus of water-energy-food in China's tourism industry. Resour. Conserv. Recycl. 2021, $164,105157$. [CrossRef] [PubMed]

91. Ringle, C.M.; Wende, S.; Becker, J.M. SmartPLS 3. SmartPLS GmbH Boenningstedt 2015. Available online: http:/ / www.smartpls. com (accessed on 8 March 2021).

92. Hair, J.F.; Ringle, C.M.; Sarstedt, M. Partial least squares structural equation modeling: Rigorous applications, better results and higher acceptance. Long Range Plan. 2013, 46, 1-12. Available online: https: / / ssrn.com/abstract=2233795 (accessed on 3 March 2021). [CrossRef]

93. Ali, Faizan, Kim, Woo Gon, Ryu, Kisang, The effect of physical environment on passenger delight and satisfaction: Moderating effect of national identity. Tour. Manag. 2016, 57, 213-224. [CrossRef]

94. Nunkoo, R.; Ramkissoon, H. Structural equation modelling and regression analysis in tourism research. Curr. Issues Tour. 2012, 15, 777-802. [CrossRef]

95. Nunkoo, R.; Ramkissoon, H.; Gursoy, D. Use of Structural Equation Modeling in Tourism Research: Past, Present, and Future. J. Travel Res. 2013, 52, 759-771. [CrossRef]

96. Ko, D.W.; Stewart, W.P. A structural equation model of residents' attitudes for tourism development. Tour. Manag. 2002, 23, 521-530. [CrossRef]

97. Eusébio, C.; Carneiro, M.J.; Caldeira, A. A structural equation model of tourism activities, social interaction and the impact of tourism on youth tourists' QOL. Int. J. Tour. Policy 2016, 6, 85-108. [CrossRef]

98. Afthanorhan, A.; Awang, Z.; Fazella, S. Perception of Tourism Impact and Support Tourism Development in Terengganu, Malaysia. Soc. Sci. 2017, 6, 106. [CrossRef]

99. Lu, A.C.C.; Gursoy, D.; Del Chiappa, G. The Influence of Materialism on Ecotourism Attitudes and Behaviors. J. Travel Res. 2016, 55, 176-189. [CrossRef]

100. Gültekin, Y.S.; Gültekin, P.; Uzun, O.; Gök, H. Use of Structural Equation Modeling in Ecotourism: A Model Proposal. Period. Eng. Nat. Sci. 2017, 5, 145-151. [CrossRef]

101. Campdesuñer, R.P.; García Vidal, G.; Sánchez Rodríguez, A.; Martínez Vivar, R. Structural equation model: Influence on tourist satisfaction with destination atributes. Tour. Hosp. Manag. 2017, 23, 219-233. [CrossRef]

102. Chaitip, P.; Chaiboonsri, C.; Kovács, S.; Balogh, P. A Structural Equation Model: Greece's Tourism Demand for Tourist Destination. Appl. Stud. Agribus. Commer. 2010, 4, 75-83. [CrossRef]

103. Miller, T.K. Structural Equation Modelling (SEM) Using LISREL. Available online: http://www.masil.org/documents/SEM.pdf (accessed on 25 February 2021).

104. Hair, J.F., Jr.; Hult, G.T.M.; Ringle, C.; Sarsted, M. A Primer on Partial Least Squares Structural Equation Modelling (PLS-SEM); Sage Publications: Thousand Oaks, CA, USA, 2014. Available online: https://digitalcommons.kennesaw.edu/facbooks2014/39/ (accessed on 10 March 2021).

105. Lohmoller, J.B. Latent Variable Path Modelling with Partial Least Squares; Physica-Verlag: Heidelberg, Germany, 1989.

106. Warren, C.; Becken, S.; Nguyen, K.; Stewart, R.A. Transitioning to smart sustainable tourist accommodation: Service innovation results. J. Clean. Prod. 2018, 201, 599-608. [CrossRef] 
107. Yi, H.L.; Tsung, H.L. How do recreation experiences affect visitors' environmentally responsible behavior? Evidence from recreationists visiting ancient trails in Taiwan. J. Sustain. Tour. 2020, 28, 705-726. [CrossRef]

108. Gössling, S.; Peeters, P. Assessing tourism's global environmental impact 1900-2050. J. Sustain. Tour. 2015, 23, 639-659. [CrossRef]

109. Chen, H.S.; Hsieh, T. An environmental performance assessment of the hotel industry using an ecological footprint. J. Hosp. Manag. Tour. 2011, 2, 1-11. Available online: https:/ / academicjournals.org/article/article1379503548_Chen\%20and\%20Hsieh\%20pdf.pdf (accessed on 27 April 2021).

110. Lee, C.C.; Chen, M.P. Ecological footprint, tourism development, and country risk: International evidence. J. Clean. Prod. 2021, 279, 123671. [CrossRef]

111. Ozturk, I.; Al-Mulali, U.; Saboori, B. Investigating the environmental Kuznets curve hypothesis: The role of tourism and ecological footprint. Environ. Sci. Pollut. Res. 2016, 23, 1916-1928. [CrossRef] [PubMed] 